\title{
Editorial
}

\section{Medical Wastes -A Dangerous Health Hazard in Bangladesh}

\author{
DOI: https://doi.org/10.3329/kyamcj.v12i3.56550
}

\begin{abstract}
Medical wastes are unwanted, unusable, unsafe, unhygienic and very often offensive by-products that are being derived from health care and health-related centers and industries. Medical wastes are biological and non-biological, solid, semisolid and liquid matters that are produced from management of patients in hospitals, clinics, diagnostic and medical research centers. It includes sharp, pointed and blunt objects like BP blades, needles, syringes, plastic and glass-wares, body fluids including blood and urine, pathological samples including pus and human tissues, dressing gauzes, cottons, bandages, toxic chemicals including metals, pathogenic microbes including bacteria, viruses, fungi, helminths ova and larvae and many other wide range of materials and pharmaceutical items including medical devices and radioactive substances etc. . $^{1,23}$
\end{abstract}

Rapid urbanization in Bangladesh and high influx of migrants to cities and towns are causing an exponential rise in medical wastes in urban and municipal areas. Bangladesh is studded with over 5000 (estimated) government and private health care institutes, hospitals, clinics and diagnostic laboratories wherefrom over twenty tons of medical wastes (estimated) are being produced in a day. But no reliable clear-cut official documents and data are available. ${ }^{2}$ Scientific knowledge and facilities for their disposal are quite heavily lacking. There are few designated landfills and bins at some particular areas for dumping these hazardous medical wastes in divisional and other major cities. In the remaining parts of the country, the situation is more dangerously alarming having no designated landfills and bins for dumping. The majority of the concerned responsible officials don't follow the principles of scientific disposal off medical wastes. Many waste pickers collect some of these wastes and sell them for reuse without sterilization or recycling. ${ }^{4}$ These medical wastes carry a huge range of environmental threats to health and life globally, inducing myriads of health hazards. In developing, underdeveloped and least developed countries like Bangladesh, treatment and disposal of medical wastes are quite neglected, as these are disposed mostly with household, other culinary and market wastes.

Unscientific disposal of medical wastes in roadside open dustbins, open pits, open fields or on roads and even when thrown to the river, canal and pond waters etc without segregation pollute the ground, soil, air, the surface and the ground waters. Thus the untreated medical wastes are getting accumulated at landfills, rivers, canals, ponds and on roads in capital, divisional, district and other municipal cities throughout the country, creating serious, dangerous and deadly public health hazards. These expose the common inhabitants to risks of infectious, parasitic and different gastrointestinal, neurological, respiratory, hepatic and renal diseases. Majority of the hospitals, clinics, laboratories and other medical centers of Bangladesh do not have their own waste treatment plants and scientific disposal policies. Some of the wastes are burnt by the city corporation officials. Unscientific and open burning of medical wastes contaminates the circum-ambient air with smokes, fogs, fumes and aerosols of dusts, soots, dioxins, furans, heavy metals, and acid gases etc. Exposure to the plastics with medical wastes that contain PVC (polyvinyl chloride) and DEHP (di-2-ethylhexyl phthalate) leads to the development of cancer, cardiac, hepatic, renal, respiratory, developmental and neurological (specially mental) disorders. ${ }^{5}$ Acute and chronic infections implicate financial burden, higher morbidities and mortalities.

Untreated dirty instruments, masks, PPEs (Personal Protective Equipments), Ryles tubes, stomach tubes, transfusion and infusion sets, IV cannulas, spinal needles, gloves, catheters, drain tubes, flatus tubes from medical wastes when reused increase the burden more and more. These bear higher risks to life and health than general wastes (from domestic and industrial arenas). Thence all medical wastes need to be identified and separated at their areas of production, treated adequately and disposed off safely. These spread diseases to the cleaners, the pickers, the collectors and the recycling staffs. Moreover, these are also highly risky to the physicians, the paramedics, the technologists, the sweepers, the care-givers, the visitors and the patients as well. Infecting microbes and other parasites, toxic chemicals enter the human and the other non-human animal bodies through the integumentary system, the respiratory tract and the alimentary tract causing and spreading corresponding myriads of diseases, thus substantially increasing mortalities and morbidities. ${ }^{6,7}$

Unscientific disposal of medical wastes even interferes with the balanced green eco-system around us. The viruses like the Human Immunodeficiency Viruses (HIV 1 and 2), the Hepatitis B Virus (HBV), the Hepatitis C Virus (HCV) pose the greatest health hazard risk from such medical wastes. Moreover, the superbugs (antibiotic resistant microbes including the multi-drug resistant tubercle bacilli and atypical resistant tubercle bacilli) spread freely from these offensive medical by-products. Many other infectious diseases like cholera, enteric fevers (typhoid and paratyphoid), anthrax, bacterial and viral pneumonias and many forms of gastro-enteritis, allergies (mild, moderate and severe) including allergic dermatitis spread freely unhindered from these detrimental wastes. ${ }^{8}$

Recently the acutely fatal illnesses implicating the respiratory, alimentary, renal, cardiovascular and hematological systems from Corona Viruses (with special attention to the novel corona virus called the COVID-19 by the World Health Organization) have added to the disease burdens worldwide. Health experts and specialists always warn the relevant authorities within the 
government, the city corporations and other municipalities for becoming prompt and active to handle the situation scientifically and efficiently with utmost priority. Responsible officials within the government, other autonomous authorities, NGOs (Nongovernment Organizations) and stake-holders put forward their commitment to neutralize the crisis. But the huge uninterrupted corruption at every point of the chain of making and implementing policies hinders the progress in this regard.

Overlooking these vulnerable stages of scientific treatment and disposal off medical wastes, people can't have a healthy precinct to breathe, to live, to survive and to thrive. Bureaucratic hindrances are very much disgusting. Neither they agree to take the responsibilities nor they allow someone to come forward taking the responsibilities. The vulnerable stages of on-site medical waste mismanagement need to be properly looked into and the formidable chain is to be interrupted to achieve the desired level of scientific handling and disposal. The MOH\&FW (Ministry Of Health and Family Welfare) of People's Republic of Bangladesh needs to march forward to work together with the ministries of environment, local government and rural development, city corporations, municipalities, local, regional and multinational stake-holders. Many of the landfills in the country are located on low-lying fields having contacts with rivers, canals, lakes, haors, baors, jheels, beels, billabongs etc. ${ }^{9,10}$ And even roadside unhygienic unscientific dumping areas are also seen causing huge environmental pollution implicating water, air and soil. Before dumping, the infected medical wastes are to be sterilized and harmful chemicals are to be converted into non-harmful ones (that is the treatment before disposal). In no ways, medical wastes are to be ad-mixed with any other garbage and wastes at any step, while in the health care centers, while are being collected and while on transport.

The untreated microbes, parasites, spores, cysts, helminths ova, poisonous chemicals quite easily spread contaminating the foods and the food chains. An authorized trained licensed team is to collect medical wastes for treatment and disposal into a "separated, boundary-marked and protected site" inside a landfill. It is quite unfortunate that the medical wastes in Bangladesh are not sterilized before dumping into the landfills. On an average nearly 0.4 million people live in each upazila (thana) and over 2.8 million people live in each district of Bangladesh. The respective responsible ministries, directorates, city corporations, municipalities are to respond and play pioneer key roles. ${ }^{8}$ No single organization or official can do the job alone. The representatives from various responding authorities and the stake-holders should come forward to comprise regulatory bodies at national, divisional, corporal, municipal, district and upazila levels for safe treatment and disposal of medical wastes following the Medical Waste (Management and Processing) Rules, 2008. The Medical Waste (Management and Processing) Rules, 2008 should not be kept merely as a simple paper in the Pandora box. Every active person or agent must be aware of the said rule. ${ }^{11,12}$ All hospitals, city corporations, municipalities, district councils and upazila parishads should and must have separate and distinct infrastructure and medical waste treatment plants. Timely follow up and audit are of utmost necessity to guarantee a success in this field. Responsibilities must not be deshouldered to a third party like NGO, but must be owned and taken seriously, and must be communicated to and shared by all. Even in the capital city of Dhaka, there are inadequate and improper medical waste management. Over twenty per cent of medical wastes in Dhaka had been identified as highly hazardous and over twenty percent are infectious. In addition, Bangladesh is lacking in having a 'Specific Chemical Policy' and 'Law'. Through this window of lacking, the mishap of medical waste mismanagement is rampant. Medical wastes are to be collected by trained, protected, health conscious cleaners. ${ }^{13,14}$

People at home like family members including children and caregivers and at pharmacies are unaware of health hazards of medical wastes. Medical wastes are there being admixed by them with home wastes and municipal garbage creating serious threats on spreading diseases predominantly infectious ones. Paramedics, collectors, cleaners, sweepers, porters, transporters, dispose officials all concerned must have adequate clear cut knowledge about handling of medical wastes, especially for disposal off. Waste pickers as they are unprotected and unaware of health hazards are seriously vulnerable to injuries specially stick and cut injuries and the corresponding infectious diseases and allergies etc. Scientific and adequate avant-grade waste management strategies are essential to make safe health and environment for all including health care workers, patients and community members against infectious, toxic and injurious wastes. Specialized collection procedures, transportation and disposal facilities are mandatory and absolutely needed. ${ }^{13}$ Strict laws and regulations are to be formulated and implemented.

The medical wastes are to be protected in a pit at least two meter deep. Incineration temperatures should be above 800 degree Celsius to ensure the death of all microbes including their so-called resistant cysts and spores. All Private and Public hospitals, Clinics, Diagnostic centers should come forward to follow the SMWMM (Standard Medical Waste Managment Models) for safe disposal of medical wastes. Best communication, cooperation, sharing and exchange of information of knowledge and experience must be there amongst all stakeholders and shareholders of the government, hospitals, communities, city corporations, municipalities and NGOs. Equally important is public awareness to implement the government policies. ${ }^{15}$ The Standard Medical Waste Management policies and strategies must build awareness and consciousness amongst the hospital staffs, the public, the waste pickers and the Tokai about the inevitable hazards and risks involved and the classical methods and procedures. Moreover, it is to be recommended for sequential in-house identification, classification, segregation and management of wastes to improve health and well-being of all persons. Experiences and knowledge should be shared with other countries and international bodies. Awareness and training amongst hospital staffs and employees can act as a pivotal model in hazardous waste minimization and management.

\section{References}

1. Karamouz M, Zahraie B, Kerachian R, Jaafarzadeh N, Mah, jouri N. Developing a master plan for hospital solid waste management: a case study. Waste Management. 2007;27:626-638. 
2. V isvanathan C. Medical Waste Management Issues in Asia. In: Asia 3rd Conference, 30 October -1 November. Tokyo, Japan; 2006.

3. World Health Organization. (2018, February 8). Health-care waste.

4. Muduli, K. and Barve A., (2012), Barriers to Green Practices in Health Care Waste Sector: An Indian Perspective, International Journal of Environmental Science and Development,Vol.3(4), August, 2012.

5. Patil GV, Pokhrel K. Biomedical solid waste management in an Indian hospital: a case study. Waste management. 2005;25:592-596.

6. Blenkharn JI. Standards of clinical waste management in UK hospitals. The Journal of Hospital Infection. 2006;62:300-303.

7. Biswas, A., Amanullah ASM and Santra S.C., (2011), Medical Waste Management in the Tertiary Hospitals of Bangladesh: An Empirical Enquiry, ASA University Review, Vol.5 (2), July-December, 2011.

8. Shareefdeen, Z.M., (2012), Medical Waste Management and Control, Journal of Environmental Protection, Vol. 3, pp. 1625-1628, 2012.

9. Environmental Assessment and Action Plan For the Health, Population and Nutrition Sector Development Program (HPNSDP) 2011-2016, February, 2011. Government of the People's Republic of Bangladesh. PP 8-9.
10. Emdadul H. Syed, MSc, MHSc, Mahmuda Mutahara, MSc and Mosiur Rahman, MSc, MHSc, Medical Waste Management (MWM) in Dhaka, Bangladesh May 2012, Home Health Care Management \& Practice 24(3):140-145.

11. PRISM Bangladesh . Survey Report on Hospital Waste Management in Dhaka City Unpublished Report. Dhaka: PRISM Bangladesh; 2005.

12. Borg MA. Safe disposal of clinical waste: where is the science? The Journal of Hospital Infection. 2006;62:243-244.

13. Lawson A. UN tackles Dhaka's medical waste. (BBC correspondent in Dhaka) 2003.

14. Patwary MA, O'Hare WT, Street G, ELahi KM, Sarker MH. Quantitative assessment of medical waste generation in the capital city of Bangladesh. Waste Management. 2009;29:2392-2397.

15. Hassan MM, Ahmed SA, Rahman KA, Biswas TK. Pattern of medical waste management: existing scenario in Dhaka City, Bangladesh. BMC Public Health. 2008:1-10.

\author{
ABM Moniruddin \\ Professor of Surgery \\ Khwaja Yunus Ali Medical College
}

